\title{
Classification of Pilonidal Sinus Disease According to Physical Examination, Ultrasonography and Magnetic Resonance Imaging Findings
}

\section{Pilonidal Sinüs Hastalığının Fizik Muayene, Ultrasonografi ve Manyetik Rezonans Görüntüleme Bulgularına Göre Sınıflaması}

\author{
(1) Yusuf Yavuz1, (1) Mehmet Aykut Yıldırım², () Murat Çakır3, (1) Alper Varman4, (1) Ömer Karahan5 \\ 1Şanlıurfa Training and Research Hospital, Clinic of General Surgery, Şanlıurfa, Turkey \\ 2Necmettin Erbakan University Meram Faculty of Medicine, Department of General Surgery, Konya, Turkey \\ ${ }^{3}$ Necmettin Erbakan University Meram Faculty of Medicine, Department of General Surgery, Division of Colorectal Surgery, Konya, Turkey \\ ${ }^{4}$ T.C. Ministry Health Konya Provincial Health Directorate Dr. Ali Kemal Belviranlı Obstetrics and Pediatrics Hospital, Clinic of General Surgery, \\ Konya, Turkey \\ ${ }^{5}$ Konya Training and Research Hospital, Clinic of General Surgery, Konya, Turkey
}

\section{IIIIIIII| ABSTRACT}

Aim: We could not find a study in the literature based on physical examination findings, ultrasonography (USG) and magnetic resonance imaging (MRI) in the treatment of pilonidal sinus. In this study, we aimed to accomplish a classification based on clinical findings, ultrasonographic and magnetic resonance to provide objective criteria for diagnosis, treatment, and recurrence follow-up of pilonidal sinus.

Method: This study included patients who presented to Necmettin Erbakan University Meram Medical Faculty, the clinic of general surgery and were diagnosed with pilonidal sinus disease between 2015 and 2016. After receiving medical history, physical examination was carried out. Then MRI and USG of the patients were ordered, and the relationship of pilonidal sinus with skin, subcutaneous tissues and surrounding were recorded and analyzed. Patients were categorized as 3 groups based on average of the sum of depth and width on MRI and USG imaging. Patients with acute abscess considered as stage 2 according to the navicular region classification were not categorized.

Results: Patients were divided into three groups according to average of the sum of width and depth on USG. It was found that duration of hospitalization, work absence and frequency of operation increased as the mean values increased. Status of being operated was statistically significantly different $(\mathrm{p}=0.007)$.

Conclusion: Patients with average of the sum of width and depth on MRI and USG;

Stage 1: $<15 \mathrm{~mm}$.

Stage 2: $15-30 \mathrm{~mm}$.

Stage 3: $>30 \mathrm{~mm}$.

In conclusion; we obtained a significant classification based on MRI and USG. We concluded that informing the patients classified according to MRI and USG on treatment procedure would be meaningful. This study will guide further studies to be conducted with a larger number of patients.

Keywords: Imaging, classification, pilonidal sinus

\section{|||||||||| ÖZ}

Amaç: Pilonidal sinüsün (PS) tedavisinde fizik muayene bulguları, ultrasonografik ve manyetik rezonans (MR) görüntülemeyi esas alan bir çalışmaya literatürde rastlamadık. Bu çalışma ile PS’nin tanı, tedavi ve nüks yönünden takibinde objektif kriterler oluşturmayı sağlayacak klinik, ultrasonografik ve MR görüntülemesine dayalı bir sınıflama yapılmasını amaçlandık.

Address for Correspondence/Yazışma Adresi: Alper Varman, MD,

T.C. Ministry Health Konya Provincial Health Directorate Dr. Ali Kemal Belviranlı Obstetrics and Pediatrics Hospital, Clinic of General Surgery, Konya, Turkey E-mail: alp.varman@gmail.com ORCID ID: orcid.org/0000-0002-1918-5143

Received/Geliş Tarihi: 24.03.2020 Accepted/Kabul Tarihi: 16.04.2020

${ }^{\odot}$ Copyright 2020 by Turkish Society of Colon and Rectal Surgery

Turkish Journal of Colorectal Disease published by Galenos Publishing House. 
Yöntem: Bu çalışmada 2015 ile 2016 yılları arasında Necmettin Erbakan Üniversitesi Meram Tıp Fakültesi Genel Cerrahi Kliniği’ne başvuran ve PS hastalığı tanısı konan hastaları kapsamaktadır. Gerekli anamnez bilgileri alındıktan sonra fizik muayaneleri yapıldı. Sonrasında hastalara (MR) ve ultrasonografi (USG) görüntülemesi yapılarak PS deri derialtı dokular ve çevre ile ilişkisi belirlenecek ve veriler tek tek dosya halinde hazırlandı.

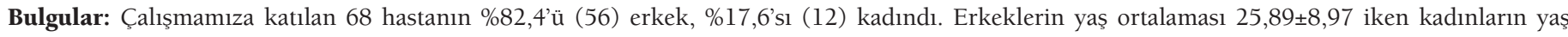
ortalaması 23,33 $\pm 8,15$ idi.

Yaptığımız MR görüntülemesinin uzunluk ve genişliğinin toplamının ortalamasına göre 3 gruba ayrıldı. Ortalama değerler arttıkça hastaneden kalış, işe gidememe durumu ve cerrahi işlem sıklığının arttığı görüldü. Cerrahi uygulanma durumu istatistiksel olarak anlamlı farklı bulunmuştur ( $\mathrm{p}=0,001$ ).

Sonuç: MR veya USG'de derinlik ve genişlikleri toplamı ortalamasına göre evreleme

Evre 1: $15 \mathrm{~mm}$ altı

Evre 2: $15-30 \mathrm{~mm}$ arasi

Evre 3: $30 \mathrm{~mm}$ üstü

Sonuç olarak yaptığımız çalışma ile MR ve USG bazında bir anlamlı bir sınıflama elde edildi. MR ve USG verilerine göre sınıflama yapılan hastaların tedavi prosedürü ve hastayı bilgilendirme açısından anlamlı olabileceği sonucuna ulaştık. Yaptığımız çalışma ileri dönemde daha fazla hasta sayısı ile yapılacak olan geniş çaplı çalışmalara öncelik oluşturacaktır.

Anahtar Kelimeler: Görüntüleme, sinıflandırma, pilonidal sinüs

\section{Introduction}

Pilonidal sinus (PS) is a common disease in the sacrococcygeal region that adversely affects the patient's life. The treatment protocol of this disease is very different, and the quality of life can be severely impaired. The aim of this disease is to make the treatment in the earliest and most appropriate way. Unfortunately, there is no common treatment protocol approach in the literature yet.

In the literature, there is no study based on physical examination findings, ultrasonography and magnetic resonance imaging in the classification of PS. With this study, we aimed to make a classification based on clinical, ultrasonography and magnetic resonance imaging that will provide objective criteria for diagnosis, treatment and follow-up of PS.

\section{Materials and Methods}

This study covered the patients who were admitted to Necmettin Erbakan University Meram Faculty of Medicine General Surgery Clinic between 2015 and 2016 and were diagnosed as having PS disease (PSD). The study was approved by Necmettin Erbakan University Meram Faculty of Medicine Ethics Committee (Date: 18.09.2015 and number: 2015/331).

Detailed information about the study was given to the patients included in the study and their written consents were obtained. A total of 70 patients participated in the study. Two patients were excluded from the study by their own wills. Demographic information of the patients participating in the study was recorded. Physical examinations were performed. The patients were classified according to the navicular region classification which was based on the physical examination findings and made by Tezel. ${ }^{1}$

After obtaining the necessary anamnesis information, physical examinations were performed. Afterwards, magnetic resonance imaging (MRI) and ultrasonography (USG) imaging were performed on the patients, and the relationship of the PS with the skin, subcutaneous tissues and the surrounding tissues was determined and the data were prepared as a single file.

Photographs of the diseased area were taken from the patients who gave permission. Pit numbers were noted. After the imaging, the results of USG and MRI were recorded. The procedure performed on our patients (surgery, conservative approach or abscess drainage), duration of hospital stay and the time to return to work in the postoperative period were recorded. All data were evaluated statistically. MRI and USG results were compared among themselves and with other values.

\section{Statistical Analysis}

Statistical analyzes were performed using SPSS version 20 software. Descriptive statistics were summarized as number, percentage, mean and standard deviation. $P$ value $<0.05$ was considered statistically significant.

\section{Results}

Of the 68 patients participating in our study, $82.4 \%(\mathrm{n}=56)$ were male and $17.6 \%(n=12)$ were female. The mean age of males was $25.89 \pm 8.97$, while the mean age of females was $23.33 \pm 8.15$. Of the patients, $42.6 \%(n=29)$ were smoking. The sociodemographic characteristics of the patients are given in Table 1.

The distance of the pits in the navicular area to the anus was evaluated. The average distance to the anus of the patients who underwent surgery was $3.09 \pm 092 \mathrm{~cm}$, and the average distance to the anus of the non-surgical group was $3.07 \pm 0.73$ $\mathrm{cm}$. The distance to the anus of the drained group was $3.36 \pm 0.92 \mathrm{~cm}$. A relationship between the surgical and nonsurgical groups in terms of the distance to the anus could 
not be determined $(\mathrm{p}=0.640)$. There was no correlation between the duration of hospital stay and the proximity of PSD to the anus ( $\mathrm{p}=0.485, \mathrm{r}=0.086)$.

While $63.2 \%(n=43)$ of the patients were hospitalized and operated, a conservative approach was preferred in $20.6 \%$ $(n=14)$ of them. Drainage was applied to $16.2 \%(n=11)$ of PS abscess (these patients were evaluated as stage 2 in the Tezel classification). The interventions performed in the patients are shown in Table 2 . No statistically significant correlation was found between smoking status and status of undergoing surgery $(p=0.058)$. No relationship was found between the smoking status of the patients and duration of hospital stay and the time to return work in the patients who underwent surgery $(\mathrm{p}=0.216, \mathrm{p}=0.351)$.

According to the Tezel classification based on the physical examination, $44.1 \%$ of the patients were in stage $3,17.6 \%$ in

Table 1. Demographic data

\begin{tabular}{lll} 
& $\begin{array}{l}\text { Number(n) } \\
\text { Percentage(\%) }\end{array}$ & Mean \pm SD \\
Gender & & \\
Male & $12(17.6)$ & \\
Female & & \\
Age & & $25.89 \pm 8.97$ \\
Male & & \\
Female & & \\
Smoking status & & \\
Smoker & $29(42.6)$ & \\
Non-smoker & $39(57.4)$ & \\
Type & & \\
Brown & $44(64.7)$ & $26.15 \pm 3.59$ \\
Blonde & $24(35.3)$ & \\
BMI & & \\
Male & & \\
Female & & \\
\hline
\end{tabular}

BMI: Body mass index

Table 2. Treatment choices

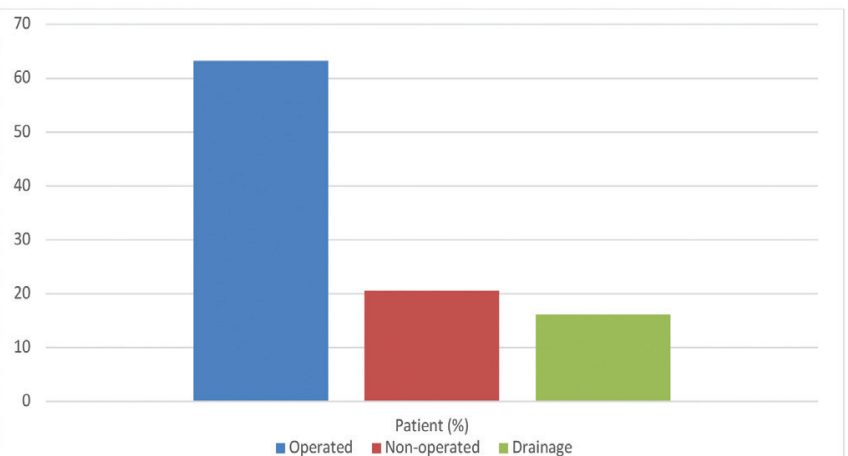

stage $1,14.7 \%$ in stage $2,14.7 \%$ in stage 4 , and $7.4 \%$ in stage 5. The clinical characteristics and stagings of the patients are given in Table 3.

The depth and width ratios of the groups measured by MRI and USG that underwent surgery, conservative approach and drainage are given in Table 4. There was a significant difference between the groups in terms of width and depth of lesion measured in MRI and width and depth of lesion measured in USG ( $\mathrm{p}=0.018, \mathrm{p}=0.008, \mathrm{p}=0.006, \mathrm{p}=0.002$ ).

Duration of hospital stay and time to return work of the patients are given in Table 5. There was a statistically significant difference between the Tezel stages of the patients in terms of duration of hospitalization and time to return work $(\mathrm{p}<0.001)$.

Drainage was applied in stage 2 patients due to abscesses. Surgery was performed in $30.8 \%(n=4)$ of stage 1 patients, $83.3 \%(n=25)$ of stage 3 patients, 90\% ( $n=9)$ of stage 4 patients, and $100 \%(n=5)$ of stage 5 patients. As the stage increased, the increase in surgical intervention was found to be statistically significant ( $\mathrm{p}=0.001$ ) (Table 6).

The patients were categorized in 3 groups by taking the average of the depth and width sum of lesion in MRI and USG imaging (Figures 1,2,3,4). In this grouping, patients with acute abscess accepted as having stage 2 according to Tezel classification were excluded from the category.

Table 3. Stage, operation and outcomes of patients

\begin{tabular}{|c|c|c|}
\hline & $\begin{array}{l}\text { Number (n), } \\
\text { Percentage (\%) }\end{array}$ & Mean \pm SD \\
\hline \multicolumn{3}{|l|}{ Stage } \\
\hline 1 & $12(17.6)$ & \\
\hline 2 & $10(14.7)$ & \\
\hline 3 & $31(44.1)$ & \\
\hline 4 & $10(14.7)$ & \\
\hline 5 & $5(7.4)$ & \\
\hline \multicolumn{3}{|l|}{ Operation } \\
\hline Yes & $43(63.2)$ & \\
\hline No & $14(20.6)$ & \\
\hline Drainage & $11(16.2)$ & \\
\hline \multicolumn{3}{|l|}{$\begin{array}{l}\text { Duration of } \\
\text { hospitalization }\end{array}$} \\
\hline Operated & & $3.88 \pm 3.19$ \\
\hline Non-operated & & 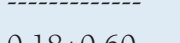 \\
\hline Drainage & & $0.18 \pm 0.00$ \\
\hline \multicolumn{3}{|l|}{$\begin{array}{l}\text { Duration of work } \\
\text { absence }\end{array}$} \\
\hline Operated & & $24.39 \pm 16.05$ \\
\hline Non-operated & & ----------------- \\
\hline Drainage & & $4.18 \pm 5.60$ \\
\hline
\end{tabular}


The patients were divided into 3 groups according to the average of the total length and width of lesion in MRI: Group 1 between 0-15 mm, group 2 between 15.1-30 mm, and group $3>30 \mathrm{~mm}$. Surgery was performed in $45 \%(\mathrm{n}=9)$ of group 1, 90\% (n=27) of group 2, and $100 \%(n=7)$ of group $3(\mathrm{p}<0.001)$ (Table 7). The duration of hospitalization and the situation of not returning to work increased significantly from group 1 to group 3 ( $\mathrm{p}<0.001$ ).

The patients were divided into 3 groups according to the average of the total length and width of lesion in USG imaging: Group 1 between 0-15 mm, group 2 between 15.1$30 \mathrm{~mm}$, and group $3>30 \mathrm{~mm}$. Surgery was performed in $52.4 \%(n=11)$ of group $1,86.7 \%(n=26)$ of group 2 , and $100 \%(n=6)$ of group 3. Surgical intervention status was found to be statistically significantly different $(p=0.007)$ (Table 8). Again, from group 1 to group 3 , the duration
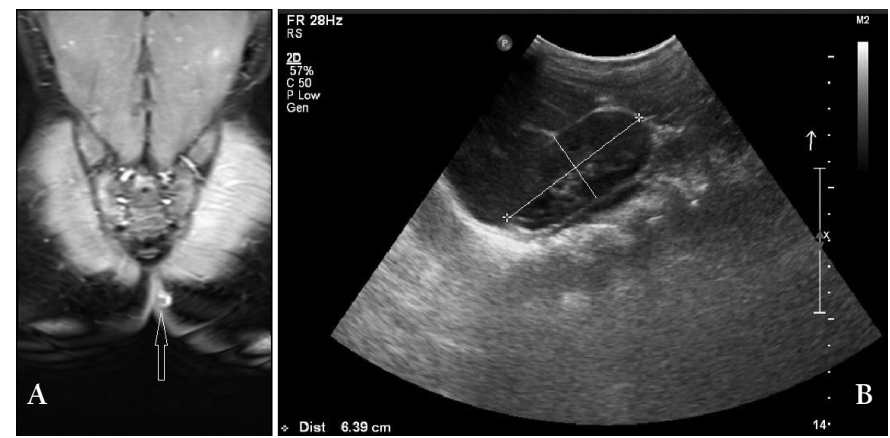

Figure 1. A) View of sinus extension on MRI coronal axial section in the patient in group 1 (width + depth $/ 2$ on MRI: $8 \mathrm{~mm}$ ), B) USG imaging of the patient with pilonidal sinus in group 1 (Average of depth and width on USG: $6 \mathrm{~mm}$ )

MRI: Magnetic resonance imaging, USG: Ultrasonograpy

Table 4. Comparison of MRI and USG measurements according to treatment method

$\begin{array}{lllll} & \text { Operated } & \text { Non-operated } & \text { Drainage } & \text { p } \\ \text { MRI depth } & 25.34 \pm 14.3 & 14.14 \pm 9.48 & 20.90 \pm 7.28 & 0.018 \\ \text { MRI width } & 20.93 \pm 15.9 & 9.35 \pm 7.16 & 11.09 \pm 4.45 & 0.008 \\ \text { USG depth } & 24.02 \pm 13.0 & 12.57 \pm 8.95 & 18 \pm 6.26 & 0.006 \\ \text { USG width } & 18.74 \pm 11.9 & 8.35 \pm 5.93 & 10.36 \pm 4.17 & 0.002 \\ \text { Duration of work absence } & 24.39 \pm 16.0 & - & 4.18 \pm 5.60 & <0.001 \\ \text { Duration of hospitalization } & 3.88 \pm 3.79 & - & 0.18 \pm 0.60 & <0.001\end{array}$

MRI: Magnetic resonance imaging, USG: Ultrasonography

Table 5. Evaluation of MRI and USG by staging

\begin{tabular}{|c|c|c|c|c|c|c|}
\hline & Stage 1 & Stage 2 & Stage 3 & Stage 4 & Stage 5 & $\mathrm{p}$ \\
\hline MR width & $6.38 \pm 5.12$ & $10.70 \pm 4.49$ & $17.06 \pm 8.91$ & $32.40 \pm 23.08$ & $25.40 \pm 17.27$ & 0.001 \\
\hline USG depth & $9.69 \pm 5.83$ & $17.80 \pm 6.56$ & $22.83 \pm 10.97$ & $30 \pm 16.32$ & $23.60 \pm 8.20$ & 0.001 \\
\hline USG width & $6.23 \pm 4.45$ & $9.90 \pm 4.09$ & $16.10 \pm 8.09$ & $26.40 \pm 13.43$ & $22 \pm 18.23$ & 0.001 \\
\hline $\begin{array}{l}\text { Duration of work } \\
\text { absence }\end{array}$ & $3.83 \pm 8.69$ & $2.60 \pm 2.06$ & $16.96 \pm 11.35$ & $31.50 \pm 23.33$ & $39.00 \pm 15.16$ & $<0.001$ \\
\hline
\end{tabular}

MRI: Magnetic resonance imaging, USG: Ultrasonography

Table 6. Treatment options by staging

$\begin{array}{llll} & \text { Operated } & \text { Non-operated } & \text { p } \\ \text { Stage } 1 & 4(30.8 \%) & 9(69.2 \%) & 0.001 \\ \text { Stage 3 } & 25(83.3 \%) & 5(16.7 \%) & \\ \text { Stage } 4 & 9(90 \%) & 1(10) & \\ \text { Stage } 5 & 5(100 \%) & 0 & \end{array}$


of hospitalization and period of not returning to work increased significantly $(\mathrm{p}<0.001)$.

\section{Discussion}

Although PSD is seen as a simple disease, it emerges as a disease with increasing frequency in the population. ${ }^{2}$

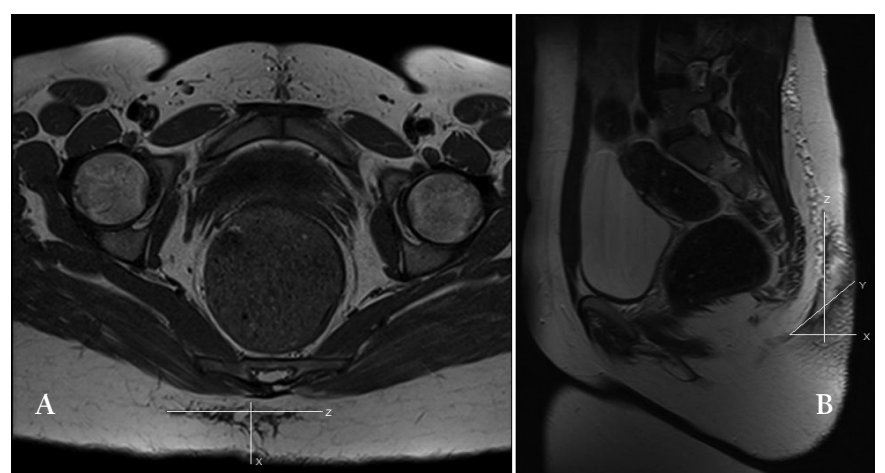

Figure 2. A) Axial T1 sequence view on MRI of the patient with pilonidal sinus in group 2. X: Distance from the skin to the fascia (depth), Z: Subcutaneous transverse spreading (width) (Patient with average of the depth and width on MRI: $22 \mathrm{~mm}$. X:15 Y:29 X+Z/2=22 mm)

B) Sagittal Tl sequence view on MRI of the patient with pilonidal sinus in group $2 \mathrm{X}$ : Perpendicular distance from the skin to the presacral fascia (deep) Y: Expansion of the sinus tract, Z: Subcutaneous transverse spreading (width)

MRI: Magnetic resonance imaging

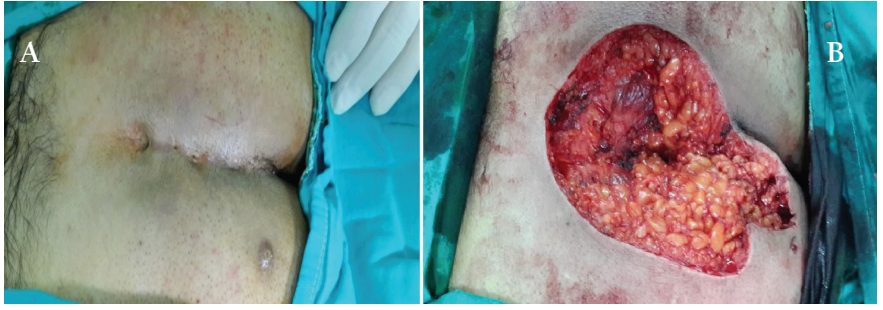

Figure 3. A) Patient with pilonidal sinus in group 3 with pits out of the navicular region, B) Operation image of our patient with pilonidal sinus in group 3
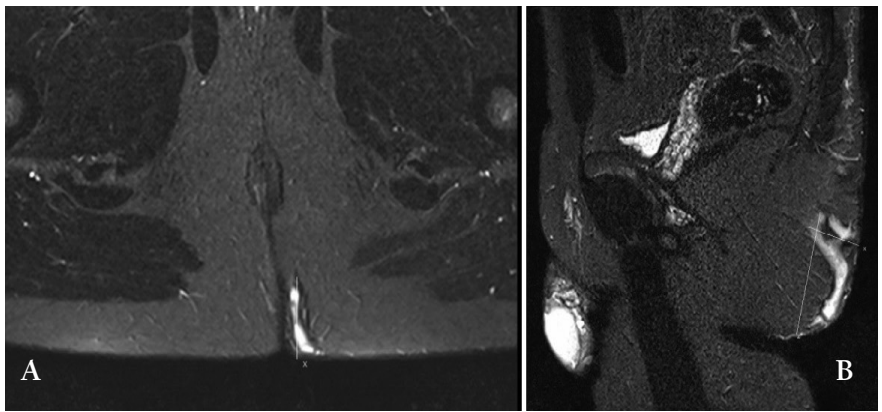

Figure 4. A) Axial Tl sequence on MRI of the patient with pilonidal sinus in group 3, B) Sagittal T1 sequence view on MRI of the patient with pilonidal sinus in group 3 (Average of depth + width on MRI $52 \mathrm{~mm}$, $\mathrm{X}: 34 \mathrm{~mm}$ Y:70 mm)

MRI: Magnetic resonance imaging

Table 7. Evaluation according to average of depth + width on MRI

$\begin{array}{lllll} & \text { Operation } & \text { Hospitalization } & \text { Work absence } & \text { p } \\ \text { Group } 1(<15 \mathrm{~mm}) & 45 \% & 0.75 \pm 1.01 & 6.60 \pm 1.52 & \mathrm{p}<0.001 \\ \text { Group } 2(\mathbf{1 5}-30 \mathrm{~mm}) & 90 \% & 3.06 \pm 2.51 & 21.23 \pm 13.61 & \mathrm{p}<0.001 \\ \text { Group } 3(>30 \mathrm{~mm}) & 100 \% & 8.57 \pm 6.34 & 40 \pm 23.62 & \mathrm{p}<0.001 \\ \text { MRI: Magnetic resonance imaging } & & & \end{array}$

Table 8. Evaluation according to average depth + width on USG

\begin{tabular}{|c|c|c|c|c|}
\hline & Operation & Hospitalization & Work absence & $\mathrm{p}$ \\
\hline Group $2(15-30 \mathrm{~mm})$ & $86.7 \%$ & $3.46 \pm 3.35$ & $21.23 \pm 14.53$ & $\mathrm{p}<0.001$ \\
\hline Group 3 (>30 mm) & $100 \%$ & $7.50 \pm 6.22$ & $39.16 \pm 26.34$ & $\mathrm{p}<0.001$ \\
\hline
\end{tabular}

USG: Ultrasonography

Table 9. Classification according to navicular region based on physical examination by Tezel ${ }^{1}$

Type I

Type II

Type III

Type IV

Type V
Asymptomatic, sinus pits in navicular region, abscess, no discharge

Acute pilonidal abscess

Sinus pits in navicular region with a history of drained abscess or discharge

One or more sinus pits out of the limits of navicular region

Patients developing recurrence 
Some surgeons prefer conservative methods in patients on the grounds that relapse is less, and some surgeons prefer based on hospitalization and time to return to work. ${ }^{3,4}$ It is obvious that PSD is an important disease due to its frequent postoperative complications and relapses, the long duration of care, and the prolonged period of not returning to work. ${ }^{5}$ PSD is a chronic inflammatory disease that occurs in the intergluteal region. The disease often affects the population aged 15-35 years. It is seen 3-4 times more frequently in men than women. ${ }^{6,7,8}$ In a study conducted by Kuvvetli et al. ${ }^{9}$, the female/male ratio was found to be $1 / 5$.6. In our study, $82.4 \%$ of the patients were male and $17.6 \%$ were female. The mean age was 24 years which was in line with the literature.

There was no study in the literature conducted to search for the relationship between smoking and the frequency of the disease. In some studies, it has been suggested that smoking causes complications seen in the early period since it causes hypoxia in peripheral tissues. ${ }^{10}$ In our study, the rate of smoking in our patients was $42.6 \%$. No significant relationship was found between the disease and smoking.

Toker et al. ${ }^{11}$ reported that $67 \%$ of the patients were darkskinned in their study. ${ }^{11}$ In our study, in line with the literatüre, $64.7 \%$ of our patients were dark-skinned and $35.3 \%$ were light-skinned.

In a study it was found that the average distance of the sinus pits to the anal wedge was $5 \mathrm{~cm} .{ }^{12}$ In our study, it was $3.2 \mathrm{~cm}$. In cases such as perianal fistula where determination of fistula tract is required, MRI has become a method used in almost all surgical clinics. ${ }^{14}$ In our study, we performed MRI and USG imaging for our patients in order to visualize the PS tract under the skin and to determine the treatment procedure accordingly. In our study, the distance (depth) of the lesion from the skin and its course (width) in parallel under the skin were evaluated with MRI and USG. No additional meaningful evaluation data were found for the presacral fascia and surrounding tissues. It was observed that as the depth of the lesion in MRI increased, the depth of the lesion in USG increased and the width of the lesion in USG increased as the width of the lesion in MRI increased. However, unlike USG, MRI provided better image quality, easier interpretation and clearer information in terms of differential diagnosis.

When we examined the MRI and USG images, no relation was found between the patient's age and the depth or width of the lesion in MRI, and the depth or width of the lesion in USG.

According to the classification made by Tezel ${ }^{1}$, patients with stage 4 disease had more pits and their pits were outside of the gluteal cleft, so depth and width of the lesion in MRI and USG were found to have higher values than other stages in this group. ${ }^{1}$ The details of the classification by Tezel ${ }^{1}$ are available in Table 9. We think that preoperative MRI and USG examinations will be valuable in patients whose pits are outside the gluteal region.

We observed that the rate of undergoing surgery, the duration of hospital stay and the period of not returning to work increased from group 1 to group 3 in patients who were categorized based on the the depth and width of the lesion in MRI and USG. Patients with PSD with acute abscess were not included in this category due to undergoing drainage procedure and then conservative or surgical procedures for PSD.

When the treatments we applied in the patients were evaluated, it was seen that we performed more surgical procedure instead of conservative treatment in patients with lesions with high depth and width in MRI and USG. It was observed that the depth and width of the lesion in MRI and USG in the patients who were treated conservatively were significantly less than the others. This shows that MRI and USG imaging to be performed during treatment planning may be important in determining the appropriate treatment protocol to be applied to the patient.

The study by Sözen ${ }^{15}$ showed that the longer the hospital stay, the longer the time to return to work. When we examined the MRI and USG values of patients with a long hospital stay and patients with long period of not returning to work, we found that as the depth and width of the lesion in MRI and USG increased, the duration of hospitalization and the period of not returning to work increased. While doing this evaluation, we excluded the patients at stage 2 in Tezel classification. We observed that patients with stage 5 disease had smaller lesions in MRI and USG compared to patients with stage 4 disease and parallel to this, the duration of hospital stay was shorter. Based on this data, we observed that performing an imaging before starting PSD treatment was important both in terms of the course of the treatment and informing the patient in the postoperative period.

When the staging performed by Tezel ${ }^{1}$ based on the navicular region was compared with the MRI and USG data, it was observed that the depth and width of the lesion in MRI and USG increased in parallel with increase in stage. However, it was observed that MRI and USG values were lower in patients with stage 5 compared to stage 4 . It was observed that the duration of hospital stay was shorter in patients with stage 5 than in patients with stage 4 . Although patients with stage 5 were accepted as having relapse, it was thought that the prognosis might be worse in stage 4 . It was thought that using imaging studies for staging in evaluating the prognosis of patients with PSD would be more meaningful.

In the study by Harlak et al. ${ }^{13}$, the average number of pits was reported as 2.71 . In our study, it was 1.92 . We could not obtain significant findings in imaging in some of our patients 
who had an average number of pits below 2 and did not have complex findings in physical examination. However, in patients who appeared to be at a more advanced stage on physical examination (those with a high number of pits outside the gluteal cleft, those with recurrent PSD, etc.), the imaging to be performed would determine the method of treatment and would predict the duration of hospitalization and period of not returning to work if surgery was to be performed. When we examined the number of pits and MRI and USG values, it was observed that as the number of pits increased, the depth of lesion in MRI and USG increased. It was concluded that MRI and USG examinations might be more meaningful in patients with more than 2 pits.

Evaluating patients with PSD only with a physical examination does not provide sufficient information about the course of the disease under the skin, and this does not provide an opportunity to make a treatment decision and does not predict the outcome of the disease.

\section{Conclusion}

As the average of depth and width of lesion in imagings increases, the rate of performing surgical treatment increases. Parallel to this, the length of stay in the hospital and the duration of not returning to work are also increasing.

Although MRI is valuable in terms of image quality and in differential diagnosis, we think that USG is as effective as MRI, and it is convenient and practical in imaging the disease. We collected MRI and USG values in the same category while doing our own staging. In the light of the data we have obtained, we suggest a staging that can give an idea about appropriate treatment method to be preferred and about the prognosis of the disease. It is possible to create a more realistic and close to ideal staging with multi-center and large population studies.

Classification of PSD without acute abscess according to the average depth and width of lesion in MRI or USG:

Stage 1: Patients whose mean depth and width of lesion in MRI or USG are less than $15 \mathrm{~mm}$ (we recommend conservative treatment in this group).

Stage 2: Patients whose mean depth and width of lesion in MRI or USG are between 15-30 mm. (Conservative approach should be considered primarily in this group.)

Stage 3: Patients whose mean depth and width of lesion is above $30 \mathrm{~mm}$ in MRI or USG. (Surgical treatment will be more appropriate in this group of patients with a large lesion.)

\section{Ethics}

Ethics Committee Approval: The study was approved by Necmettin Erbakan University Meram Faculty of Medicine Ethics Committee (Date: 18.09.2015 and number: 2015/331).
Informed Consent: Detailed information about the study was given to the patients included in the study and their written consents were obtained.

Peer-review: Externally and internally peer reviewed.

\section{Authorship Contributions}

Surgical and Medical Practices: Y.Y., A.V., Ö.K., Concept: Y.Y., Ö.K., Design: M.A.Y., Ö.K., Data Collection or Processing: Y.Y., M.Ç., Analysis or Interpretation: M.A.Y., A.V., Literature Search: Y.Y., M.Ç., Writing: M.A.Y., A.V.

Conflict of Interest: No conflict of interest was declared by the authors.

Financial Disclosure: The authors declared that this study received no financial support.

\section{References}

1. Tezel E. A new classification according to naviculararea concept for sacrococcygeal pilonidal disease.Colorectal Dis 2007;9:575-576.

2. Karahan o,pilonidal sinüs ameliyatlarındaki artış normal mi? Ulusal Cerrahi Derg 2010; 26:207-211

3. Attaallah W, Coşkın Ş, Coşkun M, Solmaz A, Yeğen C, Gençosmanoğlu R. The impact of crystalline phenol application as a minimal invasive treatment modality for pilonidal sinus disease. Turk J Colorectal Dis 2015;25:28-33.

4. Sondenaa K, Nesvik I. Recurrent pilonidal sinus after excision with closed or open treatment: final result of a randomized trial. Eur J Surg 1996;162:237-240.

5. Isbister WH, Prasad J. Pilonidal disease. ANZ J Surg 1995;65:561-563.

6. McCallum I, King PM, Bruce J. Healing by primary versus secondary intention after surgical treatment for pilonidal sinus. Cochrane Database Syst Rev 2007;17:CD006213.

7. Çubukçu A, Çubukçu D. [Pilonidal disease]. Çağdaş Cerrahi Derg 2002;16:234-238.

8. Ertan T, Koc M, Gocmen E, Aslar AK, Keskek M, Kilic M. Does technique alter quality of life after pilonidal sinus surgery? Am J Surg 2005;190:388392.

9. Kuvvetli A, Çetinkunar S, Parlakgümüş A, Evaluation of etiological risk factors in the development of adult chronic pilonidal disease. Turk J Colorectal Dis 2019;29:75-77.

10. Jensen JA, Goodson WH, Hopf HW, Hunt TK. Cigarette smoking decreases tissue oxygen.Arch Surg 1991;126:1131-1134.

11. Toker M. Pilonidal sinüslü hastalarda prognostik faktörler ve uygulanan tedavilerin morbiditeye etkileri, 2009. Available from: http://acikerisim.dicle.edu.tr/xmlui/bitstream/handle/1 1468/1683/ Pilonidal\%20sin\%C3\%BCsl\%C3\%BC\%20hastalarda\%20prognostik\%20 fakt \% C 3 \% B 6rler \% 20 ve \% 20 uygulanan $\% 20$ tedavilerin $\% 20$ morbiditeye $\% 20$ etkileri.pdf?sequence $=1$

12. Hamaloğlu E, Yorgancı K. Pilonidal sinüs. Temel cerrahi'de. ed: Sayek İ. Ankara:Güneş Kitapevi 2004:126;1273.

13. Harlak A, Menteş Ö, Özer M, Ersöz N,Coşkun A. Evaluation of History and Physical Examination Data of 587 Patients with Sacrococsigeal Pilonidal Disease. Eurasian J Med 2006;38:103-106.

14. de Miguel Criado J, del Salto LG, Rivas PF, del Hoyo LF, Velasco LG, de las Vacas MI, Sanz AGM, Paradela MM, Moreno EF. MR imaging evaluation of perianal fistulas: spectrum of imaging features. Radiographics 2012;32:175-194.

15. Sözen M. Sakrokoksigeal pilonidal sinüs cerrahi tedavisinde karydakis flep ile limberg flep ameliyat sonuçlarının karşılaştırılması. Ulusal Cerrahi Derg 2010;:153-156. 